\title{
THE ROLE OF NATIONAL FISCAL SECURITY AND TAX SOVEREIGNTY IN COLLECTION OF TAXES
}

\author{
ALEKSANDER KOSTYUKOV ${ }^{1}$, KIRILL MASLOV ${ }^{2}$
}

\begin{abstract}
This contribution deals with the issues of the collection of taxes in the fiscal security context. The main aim of the contribution is to confirm or disprove the hypothesis that collection of taxes, being the sign of tax sovereignty, is one of the most important methods of provision for national fiscal security. The methodology of the study includes general scientific methods (analysis, synthesis, induction, deduction, comparison, description) as well as particular legal academic methods (interpretation of legal acts, formal-legal method). The Authors analyze scientific approaches to the concept of national security as a generic term to the fiscal security, highlights its elements and contents. The Authors note that the state, public and personal security shouldn't be opposed each other, but they should be considered as elements of a unified system of national security. Full and effective implementation of the rights and legitimate interests of citizens and their communities equally meets the needs of national security as the protection of the interests of the state as a whole. The Authors prove that national security and tax security, in particular, are achievable only in conditions of genuine state sovereignty.
\end{abstract}

\section{Keywords}

Fiscal security; tax sovereignty; the collection of taxes; threats; methods

\section{JEL Classification: K34, M40, H71}

1 Professor for Financial Law, Head of Department of Constitutional and Municipal Law, Faculty of Law, Dostoevsky Omsk State University, Russian Federation. The Author specializes in tax law and local selfgovernment finance. He is the author of more than 10 books and more than 150 reviewed articles in prestigious legal journals. He is a member of Information and Organization Centre for the Research on the Public Finances and Tax Law in the Countries of Central and Eastern Europe. Contact email: omsk.post@ gmail.com.

2 Associate professor for Financial Law, Department of Constitutional and Municipal Law, Faculty of Law, Dostoevsky Omsk State University, Russian Federation. The Author specializes in tax law and tax administration. He is the author of 5 books and more than 40 reviewed articles in Russian legal journals. Contact email: maslov.omsu@gmail.com. 


\section{Introduction}

The main aim of the contribution is to confirm or disprove the hypothesis that collection of taxes, being the sign of tax sovereignty, is one of the most important methods of provision for national fiscal security. The main research question is how the effectiveness of the collection of taxes impacts on the provision for national fiscal security. The answer on this question will be given in the article by using general scientific methods (analysis, synthesis, induction, deduction, comparison, description) as well as particular legal academic methods (interpretation of legal acts, formal-legal method). The issues of national security and it's threats were in the focus of research of M.J. Glennon (2014), F. Alting von Geusau and J. Pelkmans (1982), A.B. Adams (1936), V.M. Redkous (2011), S.V. Kortunov (2007), S.V. Stepashin (1994), V.S. Polikarpov (2001), N.V. Mikhalkin (1993), N.N. Rybalkin (2006), A.V. Siusiukin (2004), V.I. Mayorov (1997). The issues of tax sovereignty were researched by S. Douma (2011), S. Jansen (2011), I.I. Kucherov (2017), A.I. Pogorletskiy (2005), S.V. Ovsyannikov (2001). The problems of national fiscal security and the role of the collection of taxes in ensuring of national fiscal security were not researched by lawyers sufficiently.

Although the issues of national fiscal security and efficiency of collection of taxes are very actual nowadays. The current stage of economic development of many countries is characterized by new challenges and threats, undermining the economic national security of the country, which actualizes the problem of finding solutions aimed at stabilizing the revenue part of the budgets of all levels.

Taxes and other compulsory payments are one of the key sources of budget revenues. The sovereign right of the state is anchored in the collection of taxes (Karaseva, 2001: 99, 107). "A significant proportion of tax sources in the budgets of many countries plays the [key] role in tax revenues for the stable development of the economy and national security" (Zhuravleva, Izmailova 2011: 23-26). According to experts' estimates, the tax system of the Russian Federation is close to the average world standards, while the simplicity of the interaction of taxpayers with tax authorities is quite lower than world standards. In such circumstances, the main reserve of leveling tax threats to national security is the improvement of tax administration and of the collection of taxes as its key component.

\section{Essence of National Security}

There are many similar categories connected to security: these are public security, national security, public security etc. The views of researchers on the interrelation of these categories vary widely: from identification (Redkous, 2011: 
14) to delimitation depending on the subject (the state, the titular nation, society) (Kortunov, 2007: 18). In the Russian Constitution, there are three main varieties of the security highlighted: "state security" (Constitution, Art. 13/5), "safety of citizens" (Constitution, Art. 56/1), "public security" (Constitution, Art. 72/1). The most well-reasoned, and therefore is a preferred one is a position, representing the national security as a generic term, and state security, public security, and personal security - as the species selected depending on the subject whose interests are protected (Yurchenko, Davydov, 2011: 169-173).

National security, in our view, is unacceptable to be understood in the context of protecting the interests of the titular nation, as a minimum, because the adjective "national" is derived from the English "nation", indicating not only and not so much a nation (people) but the state. Based on the National Security Strategy, the latter involves the security of the state, society and the individual in their unity.

That's why the state security, public security, and personal security should be viewed as elements of a single system of national security. "Security of the State, of society and of the individual are in dialectical relationships" (Litvinov, 2012: 67), that is based on the unity and mutual responsibility (Bashuk, 2013: 350-353). This approach involves the community on a fundamental level of the interests and needs of each security actor. That's why in the state-building process it is unacceptable to eliminate the threats to state security by infringing on the vital interests of the individual. "Security of the integrated complex social system as a set of interconnected structural elements is determined by the security of its weakest structural element" (Litvinov, 2012: 67).

That is why the full and effective implementation of the rights and legitimate interests of citizens and companies as taxpayers equally meets the needs of national security as the protection of the interests of the state as a whole.

\section{Essence of Tax Sovereignty}

The national security in general and the fiscal security, in particular, are achievable only if the true state sovereignty exists. It is possible to distinguish economic sovereignty, part of which the fiscal sovereignty is, in the structure of state sovereignty (Ostroukhov, 2009: 20). Categories of tax and fiscal sovereignty, are often used as synonyms in the legal acts and legal literature (Havanova, 2013: 41-51; Solovyova, 2015: 200; Shakhmametiev, 2014: 121). We can hardly agree with such an identification because even etymologically fiscal sovereignty (from the Latin fiscus) refers to the collection of not only fiscal but all of the budget revenues. 
There is no legal definition of tax sovereignty in Russian legal system. Some of its elements are disclosed in decisions of the Constitutional Court of the Russian Federation: there is recognition by the international community of the rights of the state to impose and collect taxes on its territory (Constitutional Court, no. 1572-O-O/2010) by enforcement unilateral actions (Constitutional Court, no. 16$\mathrm{P} / 2016$ ); the right of the state to determine indicators of assessment the financial and economic activity of the taxpayer needed for tax purposes (Constitutional Court, no. 24-P/1998). Being the kind of state sovereignty, tax sovereignty has all its attributes in the field of taxation. The Russian Constitutional Court explained that such attributes include "the supremacy, the independence, and autonomy of state power, the fullness of legislative, executive and judicial authority of the state over its territory and independence in international communication".

In the context of the tax sovereignty, the supremacy refers to the ability of the state power to impose and collect taxes and charges on the entire territory of the country in respect of any groups and individuals, regardless of their will. The independence of the state power in the field of taxation means the ability to define and implement tax policies, without being influenced by foreign governments or certain groups of taxpayers inside the country, including acting in the interests of the entire state population.

The autonomy of the state authorities is also closely connected to independence. This attribute indicates that, contrary to popular opinion (Shakhmametiev, 2014: 121; Krivyh, 2009: 44), the conclusion of international treaties, in which the state assumes the obligations in the field of taxation, does not limit tax sovereignty, but on the contrary, it is one of the ways of its realization. The possibility of denunciation of the treaties, if they cease to meet the interests of the state and will create a threat to its tax security, is not excluded. International cooperation in the area of collection taxes (the exchange of tax information, combating tax crimes, joint activities of tax authorities of various states) significantly contributes to tax security of each state.

In some aspects tax, sovereignty can be limited by the existence of the universally recognized principles and norms of international law, operating in the territory of the country directly, even if they contradict the decisions taken by bodies of the state. According to A.V. Demin, "the maintenance of tax rules is being more and more influenced by the will of the international community, which significantly limits the fiscal sovereignty and law-making discretion of the States" (Demin, 2015: 187).

It is difficult to agree with M. Orlov in his opinion that taxes are the form of limitation of the fiscal sovereignty (Orlov, 2006: 19). Taxes as compulsory payments are the manifestation of the sovereignty of the state. Legal principles of 
taxation limit sovereignty to a reasonable extent. Illustrating this limitation, the Constitutional Court of the Russian Federation noted that, although the legislator is acting within its discretionary powers while in determining the tax liabilities and possessing fiscal sovereignty, tax regulation should have a sufficient degree of certainty. Tax sovereignty can be limited (but only by the national courts) in the case and to the extent when decisions of legislative bodies in the tax area are going to become a threat to national fiscal security. Thus, Art. 2/4 of the General Part of the Tax Code of the Republic of Belarus prohibits the establishment of taxes, dues (duties) and benefits which can threat to national security of Belarus, its territorial integrity, political and economic stability (Pilipenko, 2006: 21-31).

Full power means the ability of the state to exercise legislative power, governance and law enforcement in tax relations throughout the country without the need of anyone to agree on decisions. It is difficult to accept the position that every subject of tax policy (including regions and municipalities) may have sovereignty within the limited powers (Ovchinnikova, 2008: 56).

Scholars of constitutional law mention the unity of state power as an important sign of sovereignty (Kazannik, Kostyukov, 2016: 7). With regard to the field of taxation, the unity means the system integrity of the bodies forming and implementing tax policy (Ministry of Finance of Russia and his subordinate authorities). From the standpoint of maintaining the tax sovereignty the Russian legislator's decision to transfer the right to initiate the criminal prosecution for tax crimes from the specialized system of tax authorities to the investigation bodies should be assessed negatively. On the contrary, from the viewpoint of the unity of state power, the tax authorities should be empowered to operational and investigative activities.

It is unacceptable to reduce the implementation of tax sovereignty only to the imposition and collection of taxes. The external manifestation of tax sovereignty includes:

- the imposing of taxes on the territory of the state (Kucherov, 2009: 191; Orlov, 2006: 19), as well as for the entities, economically related with the state;

- the collection of taxes, including their unilateral recovery (Gaudmet, 1978: 371), as well as the rejection of their collection ("tax amnesty") (Pokachalova, Belova, 2015: 28-31);

- establishing and implementing control and accountability mechanisms in the tax field (Pogorletskiy, 2005: 10);

- the resolution of disputes between the participants of tax relations (Ovsyannikov, 2001: 11-12). 
Thus, essential characteristics and forms of implementation of tax sovereignty are in a systemic relationship. Because it is difficult to agree with the view that, by their nature, tax sovereignty is a set of fragmented principles, entered the practice of states though (Kudryashova, 2005: 35-43).

\section{Key Features of National Fiscal Security}

There are a few scientific approaches to the content of "security" as the general category and to the category of "national security":

- Security as a characteristic of the society as of a complex system in its functioning and development (systematic approach) (Stepashin, 1994: 23; Polikarpov, 2001: 109).

- Security as the level of public relations, ensuring their further sustainable development (sociological approach) (Mikhalkin, 1993: 48).

- Security as a conscious need of the subject, or the value (axiological approach) (Rybalkin, 2006: 52).

- Security as the activity of the subjects to stop threats (dynamic approach) (Timokhin, 1993: 30).

- Security as a condition of protection (Tropin, 2004: 31-35), when there are no danger (Belov, 1994: 88) or threats (static approach) (Rozhdestvenskiy, 1995: 83). In this context, the terms characterizing certain types of national security are classically used in legal research (Mayorov, 1997: 12; Siusiukin, 2004: 8-9) and in legislation.

In the legal sense, taking into account the conventional approaches to the subject of legal regulation, national security should be understood primarily as the level of development of public relations in the state. Etymologically, "security" is "no danger". Because of it, the protection of public relations from the negative impact of threatening their existence should be one of the objectives of national security. The second equal task of national security is the development of public relations according to values established in the society. "The phenomenon of security initially is not associated with the presence of danger, but with the desire of the subject to preserve its existence, the opportunity to continue to develop in accordance with his nature" (Guskov, Reznik, 2013: 18). The preservation of any phenomenon in a dynamically changing world is impossible without continuous improvement of its key elements. Sustainable socio-economic development is identified as one of the goals of national security in the eponymous Strategy approved by the President of the Russian Federation. 
Thus, national security can be defined as a level of development of social relations in the state, in which their protection from internal and external threats is ensured in accordance with national values. In accordance with the above mentioned approach national fiscal security is a level of development of social relations in fiscal sphere when the amount of collecting taxes corresponds to the number of planned tax revenues taking into account the need for full funding of all functions and tasks of the state and municipalities both in the current period and in the future. This level could be achieved only with systematic and continuous work of all participants of public relations.

\section{Threats to Tax Sovereignty and National Fiscal Security}

Taxation in the state can be described as the process aimed at achieving a status of national fiscal security by eliminating its threats and ensure compliance between such process and indicators of the national tax security. The identification of threats and indicators of the national fiscal security allows us to specify the orientation of legal regulation, to prevent the development of negative trends of taxation as a social process by legal methods, as well as to assess the effectiveness of legal means adequately.

The threat is explained in sociological theory as the presence of a certain external objective and subjective factor, which can cause negative and dangerous consequences regardless of the will and behavior of the recipient. The threat is a real possibility of destructive changes caused by external factors in respect of objects, subjects, statuses important and valuable to society and the individual. Keywords in this definition are "the external factors" and "the negative effects". Meanwhile, not only external factors but internal and inherent properties of the object also may become threats to the object of security. Thus, the process of taxation in the state can be influenced destructively by the actions of other states, by the defects of the legal technique of the national tax bills; and by the tax evasion by taxpayers due to their subjective feeling of heaviness of the tax burden.

Thus, the threats to national fiscal security can be defined as the external objective and subjective factors, as well as specific manifestations of the properties of the process of taxation, leading to a lack of tax revenues of the state in comparison with the amount necessary for full funding of all functions and tasks of the state and municipalities both in the current period and in the future. The correspondence between taxes planned and collected while the country's GDP grows and the expenditure obligations of the state and municipalities are executed is the indicator of national tax security. Legal regulation of tax relations should be aimed at eradication the identified threats to the fiscal security and achievement of its 
indicators, by the usage of regulating the impact of legal tools on the process of taxation.

Tax sovereignty of any state is continually subjected to "trial of strength" on the part of other subjects. Threats to tax sovereignty, as well as to tax security, depending on the source of origin can be divided into public (emanating from the authorities of the government and state-like entities) and private (the sources are persons without public-legal status). Threats can be classified into internal and external. Internal threats originate in the territory under the jurisdiction of the state. Among them, there are attempts of the regions to break the unity of the tax system of the country, up to the "tax separatism". Source of occurrence of external threats can be found outside the territory of the State, like actions and decisions of other states or MNEs.

Tax competition may contribute to the improvement of the tax system of competing states. However, in a situation where it is associated with the provision of the benefits of an administrative nature (in particular, concealment of information on the beneficiaries of the business) it is a serious challenge to the sovereignty and security of other countries. The value of tax sovereignty is that its presence allows the state to pursue an independent tax policy to meet their needs of the population living in the territory of the state. Because of it the obstacles in the implementation of tax sovereignty ultimately threaten the national fiscal security.

\section{Ratio of Tax Sovereignty and National Fiscal Security}

Scholars speak about synonymous meanings of the terms "economic sovereignty" and "economic security", and, therefore, their manifestations in the tax field (Boldyrev, 2014: 71-75). We believe that these concepts cannot be synonymous. Providing of peoples' security should be the sole purpose of existence (functioning) of the state and of realization of its sovereignty (Egorov, 2001: 121). The financial activity of the state is carried out "in order to implement the tasks of social and economic development, maintaining national defense and security of the country" (Khimicheva, 2012: 86). Tax, when it is considered from the standpoint of atomic theory (theory of benefits) is a cost made by each person in order to ensure personal and property security by the protection of the state (Montesquieu, 1955: 77). "People agree to pay taxes as a way to reward those who provide services to the people security" (Bastiat, 2006: 232).

Proper collection of taxes is recognized by the Constitutional Court of the Russian Federation as the condition of proper maintenance of functions of public power. According to Art. 55 of the Russian Constitution, the establishment of taxes is a reasonable limitation of private property rights, as it is necessary "in order to protect 
The Role of National Fiscal Security and Tax Sovereignty in Collection of Taxes

the constitutional order, morality, health, rights and lawful interests of others, national defense and state security". "Enforcing tax liabilities is the necessary condition of the financial independence of the state and, consequently, its economic security" (Kucherov, Kikin, 2011: 25). Thus, the tax sovereignty is a key factor in ensuring of the national fiscal security.

\section{Collection of Taxes in the Scope of National Fiscal Security}

Legal ensuring of national fiscal security may be performed by using a range of methods of rulemaking and enforcement nature. Adopting of legal enforcement acts in the sphere of the collection of taxes is a key tool for fiscal authorities in implementing their powers to ensure the national fiscal security, because the effective collection of taxes actually express the force of tax law (Alekseev, 1971: 144). "Tax collection as a form of implementation of the rules of tax law contributes to the development and protection of existing fiscal relations and the formation of new means of creating new legal facts, providing subjective rights and laying the legal obligations on the parties of the tax process, the imposing of tax liability" (Dementiev, 2013: 21).

The above-mentioned tasks of tax collection entirely meet the objectives of ensuring national fiscal security and it allows us to talk about the collection of taxes as a key method of ensuring national fiscal security.

\section{Conclusions}

The interests of the national fiscal security, based on the identified it's sovereign nature, of course, must be taken into account in the tax collection procedures. Ignoring threats of national fiscal security by tax authorities during tax collection reduces the level of security and does not meet the objectives of the implementation of the law in a sovereign state. So the aims of the research were met. It is approved that collection of taxes, being the sign of tax sovereignty, is one of the most important methods of provision for national fiscal security.

\section{References}

Adams, A.B.: National Economic Security, Oklahoma: University of Oklahoma Press, 1936.

Alekseev, S.S.: Социальная ценность права в советском обществе (Social value of law in Soviet society), Moscow: Yurid. lit. Publ., 1971. 
Alting von Geusau, F., Pelkmans, J. (eds.): National Economic Security: Perceptions, Threats, and Policies, Tillburg: John F. Kennedy Institute, 1982.

Bashuk, V.V.: Понимание национальной безопасности в философско-правовом и социокультурном аспектах (Understanding of national security in the philosophical, legal and socio-cultural aspects), Теория и практика общественного развития (Theory and practice of social development) no. 9 (2013).

Bastiat, F: Грабеж по закону (Robbery by law), Chelyabinsk: Socium, 2006.

Belov, P.G.: Системные основы обеспечения национальной безопасности России (Systematic way of ensuring the national security of Russia), Безопасность (Security) no. 6 (1994).

Boldyrev, O.Y.: Вызовы глобализации и проблемы защиты экономического суверенитета государства (The challenges of globalization and problems of protection of the economic sovereignty of the state), Конституционное и муниципальное право (Constitutional and municipal law) no. 5 (2014).

Dementiev, I.V.: Налоговое правоприменение как форма реализации налогового права (Тах enforcement as a form of realization of the tax law), Финансовое право (Finanaial law) no. 6 (2013).

Demin, A.V.: Принцип определенности налогообложения (The principle of certainty in taxation), Moscow: Statut Publ., 2015.

Douma, S.: Optimization of Tax Sovereignty and Free Movement, Amsterdam: IBFD Publications BV, 2011.

Egorov, S.N.: Аксиоматические основы теории права (Axiomatic foundations of the theory of law), Saint-Petersburg: Lexicon Publ., 2001.

Gaudmet, P.М.: Финансовое право (Financial law), Moscow: Yurid. lit. Publ, 1978.

Glennon, M.J.: National Security and Double Government, Oxford: Oxford University Press, 2014.

Guskov, Yu.V., Reznik, E.P.: Безопасность: проблемы постижения сущности (Security: the problem of understanding the nature), Науковедение (Sciencelogy) no. 5 (2013).

Havanova, I.A.: Фискальный (налоговый) суверенитет и его границы в интеграционных образованиях (Fiscal (tax) sovereignty and its borders in integration formations), Журнал российского права (Journal of Russian law) no. 11 (2013).

Jansen, S. (ed.): Fiscal Sovereignty of the Member States in an Internal Market: Past and Future, Amsterdam: Kluwer Law International, 2011.

Karaseva, M.V.: Финансовое правоотношение (Financial relationship), Moscow: Norma Publ., 2001.

Kazannik, A.I., Kostyukov, A.N. (eds.): Конституционное право: Университетский курс (Constitutional law: University course: textbook), vol. 2, Moscow: Prospect Publ., 2016.

Khimicheva, N.I. (ed.): Финансовое право: учебник (Financial law: Textbook), Moscow: Norma Publ., 2012. 
The Role of National Fiscal Security and Tax Sovereignty in Collection of Taxes

Kortunov, S.V.: Концептуальные основы национальной и международной безопасности (Conceptual fundamentals of national and international security), Moscow: HSE Publ., 2007.

Krivyh, I.A.: Источники налогового права Российской Федерации: понятие, проблемы классификации, основные принципы действия (Sources of the tax law of the Russian Federation: concept, classification problems, basic principles of action. Doctor (higher doctorate) Thesis, Ekaterinburg: Ural Federal University, 2009.

Kucherov, I.I.: Теория налогов и сборов (правовые аспекты) (Theory of taxes and duties (legal aspects)), Moscow: Junifor, 2009.

Kucherov, I.I., Kikin, A.I.: Меры налогово-процессуального принуждения (Measures of the tax procedural coercion), Moscow: Jurisprudence, 2011.

Kudryashova, E.V.: Юрисдикция (суверенитет) государств и налоговый иммунитет в области косвенного налогообложения (Jurisdiction (sovereignty) of States and tax the immune system in indirect taxation), Финансовое право (Financial law) no. 10 (2005).

Litvinov, E.P.: Философские основы концепции безопасности (Philosophical foundations of the concept of security), Пространство и время (Space and time) no. 1 (2012).

Mayorov, V.I.: Административно-правовые проблемы управления обеспечением безопасности дорожного движения (Administrative-legal problems of management of safety of traffic. Doctor (higher doctorate) Thesis, Ekaterinburg: Ural Federal University, 1997.

Mikhalkin N.V.: Безопасность Российской Федерации. Вопросы теории и практики (Тhe Security of the Russian Federation. Issues of theory and practice), Moscow: Time Publ., 1993.

Montesquieu, Ch.: The spirit of laws. Selected works, vol. 1, London: Liberty Fund, 1777.

Orlov, M.Yu.: Налог как форма разумного ограничения фискального суверенитета государства (Tax as a form of reasonable limit fiscal sovereignty of the state), Финансовое право (Financial law) no. 2 (2006).

Ostroukhov, B.A.: Международно-правовые проблемы фискального суверенитета государства (International legal and fiscal issues of state sovereignty), Юридический мир (Legal world) no. 3 (2009).

Ovchinnikova, N.O.: Налоговое планирование и налоговый контроль со стороны правоохранительных органов (About tax planning and tax control by law enforcement agencies: a practical guide), Moscow: Dashkov and Co. Publ., 2008.

Ovsyannikov, S.V.: Конституционно-правовые основы налоговых отношений (Constitutional and legal basis of tax relations. Doctor (higher doctorate) Thesis, Saint-Petersburg: SaintPetersburg University, 2001.

Pilipenko, A.А.: Экономико-правовые начала формирования налоговой системы (Economic and legal principles of formation of tax system), Финансовое право (Financial law) no. 10 (2006).

Pogorletskiy, A.I.: Принципы международного налогообложения и международного налогового планирования (Principles of international taxation and international tax planning), Saint-Petersburg: State University Publ., 2005. 
Pokachalova, E.V., Belova, T.A.: «Налоговая амнистия» в системе финансово-правовых понятий и институтов (“Тах Amnesty" in the system of financial and legal concepts and institutions), Налоги (Taxes) no. 2 (2015).

Polikarpov, V.S.: Философия безопасности (Philosophy of security), Saint-Petersburg, Rostov-onDon, Taganrog, 2001.

Redkous, V.M.: Административно-правовое обеспечение национальной безопасности в государствах - участниках Содружества Независимых Государств (Administrativelegal provision of national security in the States - participants of Commonwealth of Independent States). Doctor (higher doctorate) Thesis, Moscow: Moscow State University, 2011.

Rozhdestvenskiy, Yu.V.: Безопасность России и словесность (тезисные суждения) (Security of Russia and the literature (abstracts of judgment)), Безопасность (Security) no. 3 (1995).

Rybalkin, N.N.: Философия безопасности (The philosophy of security), Moscow: MPSI Publ., 2006.

Shakhmametiev, A.А.: Международное налоговое право (International tax law), Moscow: International relations Publ., 2014.

Siusiukin, A.V.: Административно-правовое регулирование экономической безопасности (Administrative-legal regulation of economic security. Doctor (higher doctorate) Thesis, Rostov-on-Don: Southern Federal University, 2004.

Solovyova, N.A. (ed.): 101 термин налогового права: краткое законодательное и доктринальное толкование (101 term of tax law: the legislative and doctrinal interpretation), Moscow: Infotropic Media Publ., 2015.

Stepashin, S.V.: Безопасность человека и общества (политико-правовые вопросы) (The safety of person and society (political and legal issues)), Saint-Petersburg, 1994.

Timokhin, P.P.: К формированию концепции безопасности России (Formation of the concept of Russia’s security), Безопасность (Security) no. 6 (1993).

Tropin, S.A.: Экономическая безопасность России (Economic security of Russia), Законодательство и экономика (Legislation and economics) no. 5 (2004).

Yurchenko, M.V., Davydov, A.V.: Научно-теоретические основания категории «национальная безопасность России» (Scientific-theoretical bases of a category "national security of Russia”), Вестник Бурятского государственного университета (Herald of Buryat State University) no. 6 (2011).

Zhuravleva, O.O., Ismailova, L.Yu.: Проблемы унификации подходов к налоговому администрированию (Problems of unification of approaches to tax administration), Финансовое право (Finanaial law) no. 10 (2011).

RU: Constitutional Court, no. 1572-O-O/2010.

RU: Constitutional Court, no. 16-P/2016.

RU: Constitutional Court, no. 24-P/1998. 